\title{
Metoclopramide-induced acute dystonic reactions: a case report
}

\author{
Ritesh Chaudhary*, Gyanendra Malla and Monika Kadayat
}

\begin{abstract}
Background: Acute dystonic reactions caused by drugs are uncommon in daily practice, whether in outpatient or in emergency settings. Such types of unfavorable reaction may cause the treating physician's working diagnosis to be misled at a certain point.

Case presentation: A 25-year-old Hindu female from Dharan with no previous medical history was being treated for acid peptic disease. Her local physician prescribed oral tablet metoclopramide $10 \mathrm{mg}$ three times a day for 7 days and tablet pantoprazole $40 \mathrm{mg}$ once daily for 7 days. After 24 hours of ingestion of $10 \mathrm{mg}$ of tablet metoclopramide, she was admitted to our Koirala Institute of Health Sciences emergency department with sudden history of facial twitching, slurred speech, and abnormal tongue protrusion. Metoclopramide-induced acute dystonic reaction was diagnosed. After resuscitation, her symptoms reduced quickly, and she was successfully discharged home the same day.

Conclusions: Early diagnosis would be aided by the use of clinical background along with focus on drug history usage, preventing life-threatening pitfalls. To decrease the acute dystonic reaction associated with metoclopramide use, higher frequency of prescription patterns should be taken into account.
\end{abstract}

Keywords: Acute dystonic reaction, Metoclopramide, Nepal

\section{Introduction}

Metoclopramide, an antiemetic medication, has been available in the USA since its approval by the Food and Drug Administration (FDA) in 1979. It is frequently used to treat esophageal reflux disease, dyspepsia, and gastroenterologic motility abnormalities, and to speed up stomach emptying time [1,2]. Metoclopramide is a benzamide that acts as a dopamine receptor antagonist and is classified as a cholinomimetic (that is, increases the transmission of acetylcholine at muscarinic receptors) $[3,4]$.

The involuntary, prolonged, or spasmodic contractions of muscle groups that result in twisting, repeated, and aberrant postures are known as drug-induced acute dystonic reactions. If left untreated, such a problem can result in airway obstruction, temporomandibular joint

*Correspondence: ritesh948@yahoo.com General Practice and Emergency Medicine, B.P Koirala Institute of Health Sciences, PO Box: 7053, Dharan, Nepal dislocation, and oropharyngeal dysphagia [5]. When patients are administered metoclopramide or prochlorperazine, it has been observed that acute dystonic reaction occurs in $0.5-1 \%$ of cases [6]. Female patients, children, and individuals under the age of 30 years who received higher doses of metoclopramide had greater incidence [7]. Although many of the cases have been reported in Western countries, comparable occurrences have also been documented in Nepal and India $[8,9]$.

As a result, we present a similar and rare case of metoclopramide-induced acute dystonic reaction (MIADR) in the emergency department of a tertiary hospital in eastern Nepal.

\section{Case presentation}

A 25-year-old unmarried Hindu female student from Dharan, Nepal, was brought to the emergency department of BPKIHS on 24 December 2019 at 4 pm with a 2 hour history of facial twitching, slurred speech, and original author(s) and the source, provide a link to the Creative Commons licence, and indicate if changes were made. The images or other third party material in this article are included in the article's Creative Commons licence, unless indicated otherwise in a credit line to the material. If material is not included in the article's Creative Commons licence and your intended use is not permitted by statutory regulation or exceeds the permitted use, you will need to obtain permission directly from the copyright holder. To view a copy of this licence, visit http://creativecommons.org/licenses/by/4.0/. The Creative Commons Public Domain Dedication waiver (http://creativeco mmons.org/publicdomain/zero/1.0/) applies to the data made available in this article, unless otherwise stated in a credit line to the data. 
24 hour history of abnormal tongue protrusion. There was no documented history of any drug allergies or other abnormal body movements. She also did not have any relatives with seizure disorders. On 23 December, her local physician prescribed oral tablet metoclopramide $10 \mathrm{mg}$ three times a day for 7 days and tablet pantoprazole $40 \mathrm{mg}$ once every day for 7 days to prevent gastric acid and basal acid secretion for acid peptic disease (APD). On examination, her Glasgow Coma Scale (GCS) was 15, blood pressure $120 / 90 \mathrm{mmHg}$, pulse rate $102 / \mathrm{min}$, and partial pressure oxygen saturation $\left(\mathrm{SpO}_{2}\right) 99 \%$ on room air. Her arterial blood gas (ABG) revealed potential of hydrogen $\left(\mathrm{P}^{\mathrm{H}}\right)$ of 7.43 , partial pressure of carbon dioxide $\left(\mathrm{PCO}_{2}\right)$ at $31.1 \mathrm{mmHg}$; sodium ion $\left(\mathrm{Na}^{+}\right) 140.3 \mathrm{mmol} / \mathrm{L}$, potassium ion $\left(\mathrm{K}^{+}\right) 3.87 \mathrm{mmol} / \mathrm{L}$, concentration of hydrogen carbonate $\left(\mathrm{HCO}_{3}{ }^{-}\right) 21.2 \mathrm{mmol} / \mathrm{L}$. The Naranjo Adverse Drug Reaction Probability Scale scored 6 and classified as a "probable" adverse drug reaction [10]. Metoclopramide-induced acute dystonic reaction was diagnosed, and she was triaged as Australasian Triage Score (ATS) 2. She was resuscitated right away with intravenous fluids, oxygen via face mask, and a $25 \mathrm{mg}$ intravenous dose of chlorpheniramine. After 2 hours, the symptoms subsided, and she was able to return home the same day. The patient was recommended to stop taking metoclopramide in the future.

\section{Discussion}

Extrapyramidal adverse effects such as acute dystonia, tardive dyskinesia, akathisia, and drug-induced Parkinsonism have been associated with the use of metoclopramide as an antiemetic.

Metoclopramide-induced acute dystonic reaction (MIADR) are found in 1:500 individuals [9], with a young female preponderance of up to $70 \%[7,11]$, which was similar to our patient, a 25 -year-old female, and could be a risk factor.

Following administration of metoclopramide, symptoms of MIADR may take up to 36 hours to appear, which is similar to our patient, who developed symptoms before 36 hours, which is comparable with another study [7].

According to the study, MIADR is thought to be associated with daily administration of more than $30 \mathrm{mg}$ of metoclopramide [12]. However, MIADR was also observed even at the recommended dosage, which is comparable to our case. The patient was prescribed oral tablet metoclopramide $10 \mathrm{mg}$ three times a day, which is similar to other studies reported from Nepal and India [8, 9].

Twitching of facial muscles, slurred speech, and aberrant rhythmic tongue protrusion are the most common symptoms of MIADR. However, throat discomfort and mild aphonia have also been reported as subtle presentation $[7,8,13]$. Other studies have also reported that these patients may present with combination of symptoms, including acute chorea [14], organic affective syndromes [15], and major depressive illness [16].

In the treatment of MIADR, diphenhydramine, anticholinergic benztropines are commonly used. Diazepam is utilized in refractory situations. Most of the signs and symptoms subsided after 5-15 minutes [17, 18]. Diphenhydramine and benztropine can improve the treatment of dystonia induced by antiemetics and psychotropic drugs [19].

Antihistamines are also effective for treating dystonia and reducing allergic manifestations [20,21]. Intravenous chlorpheniramine $25 \mathrm{mg}$ was used successfully to treat our patient.

MIADR is a rare emergency department presentation that can be easily overlooked or misinterpreted as conversion disorders or seizures. It can appear alone or in combination in normal prescribed dosages, posing serious challenges to diagnosis with a high chance of uncertainty.

\section{Conclusions}

Emergency clinicians should be proficient in detecting MIADR effectively, allowing them to avoid potentially life-threatening situations. The greater frequency of metoclopramide prescription patterns, as well as the significant adverse dystonic reaction associated with its usage, should be taken into account.

\section{Abbreviations}

APD: Acid peptic disease; ATS: Australasian Triage Score; ABG: Arterial blood gas; BPKIHS: BP Koirala Institute of Health Sciences; FDA: Food and Drug Administration; GCS: Glasgow Coma Scale; Hg: Mercury; mm: Millimeter; MIADR: Metoclopramide-induced acute dystonic reaction; $\mathrm{mmol} / \mathrm{L}$ : Millimoles per liter; $\mathrm{PCO}_{2}$ : Partial pressure of carbon dioxide; $\mathrm{SPO}_{2}$ : Partial pressure oxygen saturation; $\mathrm{P}^{\mathrm{H}}$ : Potential of hydrogen; $\mathrm{Na}^{+}$: Sodium ion; $\mathrm{K}^{+}$: Potassium ion; $\mathrm{HCO}_{3}$ : Concentration of hydrogen carbonate.

\section{Acknowledgements}

The authors would like to thank all the staff and healthcare workers of emergency ward for taking care of this patient until her discharge.

\section{Authors' contributions}

RC: managed the patient, acquisition of data, and write-up of initial manuscript and discussion. GM: critical revision of manuscript. MK: managed the patient and reviewed the manuscript. All authors read and approved the final manuscript

\section{Funding}

None.

\section{Availability of data and materials}

The datasets used and/or analyzed during the current study are available from the corresponding author on reasonable request. 


\section{Declarations}

\section{Ethics approval and consent to participate}

The study was performed in accordance with the guidelines of the Institutional Review Committee of BP Koirala Institute of Health Sciences.

\section{Consent for publication}

Written informed consent was obtained from the patient for publication of this case report and any accompanying images. A copy of the written consent is available for review by the Editor-in-Chief of this journal.

\section{Competing interests}

The authors declare that they have no competing interests.

Received: 23 December 2020 Accepted: 13 September 2021

Published online: 24 October 2021

\section{References}

1. Miller LG, Jankovic J. Metoclopramide-induced movement disorders: clinical findings with a review of the literature. Arch Intern Med. 1989;149(11):2486-92.

2. Pasricha PJ, Pehlivanov N, Sugumar A, Jankovic J. Drug insight: from disturbed motility to disordered movement-a review of the clinical benefits and medicolegal risks of metoclopramide. Nat Clin Pract Gastroenterol Hepatol. 2006;3(3):138-48.

3. Morgan GE, Mikhail MS, Murray MJ. Adjuncts to anesthesia. In: Morgan GE, Mikhail MS, Murray MJ, editors. Clinical anesthesiology. 5th ed. New York: Lange Medical Books/McGraw-Hill Medical Publishing Division; 2013. p. 292-308.

4. Moos DD, Hansen DJ. Metoclopramide and extrapyramidal symptoms: a case report. J Perianesth Nurs. 2008;23(5):292-9.

5. Oyewole A, Adelufosi A, Abayomi O. Acute dystonic reaction as medical emergency: a report of two cases. Ann Med Health Sci Res. 2013;3(3):453-5.

6. Bateman DN, Darling WM, Boys R, Rawlins MD. Extrapyramidal reactions to metoclopramide and prochlorperazine. Q J Med. 1989;71(264):307-11.

7. Tianyi FL, Agbor VN, Njim T. Metoclopramide induced acute dystonic reaction: a case report. BMC Res Notes. 2017;10(1):32.
8. Thapa A, Pant MN. Metoclopramide and acute dystonia: a case report. J Gen Pract Emerg Med Nepal. 2019;6(8):40-2.

9. Arumugam J, Vijayalakshmi AM. Metoclopramide-induced oculogyric crises presenting as encephalitis in a young girl. Indian J Pharmacol. 2012:44(2):266-7.

10. Naranjo CA, Busto U, Sellers EM, et al. A method for estimating the probability of adverse drug reactions. Clin Pharmacol Ther. 1981;30(2):239-45.

11. Ganzini L, Casey DE, Hoffman WF, McCall AL. The prevalence of metoclopramide-induced tardive dyskinesia and acute extrapyramidal movement disorders. Arch Intern Med. 1993;153(12):1469-75.

12. Leus $M$, van de Ven $A$. An acute dystonic reaction after treatment with metoclopramide. N Engl J Med. 2015;373(14): e16.

13. Freudenreich $O$. Atypical laryngeal dystonia caused by an antiemetic. Am Fam Physician. 2004;69(7):1623.

14. Dubow JS, Leikin J, Rezak M. Acute chorea associated with metoclopramide use. Am J Ther. 2006;13(6):543-4.

15. Weddington WW Jr, Banner A. Organic affective syndrome associated with metoclopramide: case report. J Clin Psychiatry. 1986:47(4):208-9.

16. Anfinson TJ. Akathisia, panic, agoraphobia, and major depression following brief exposure to metoclopramide. Psychopharmacol Bull. 2002;36(1):82-93.

17. Akbuga-Ozel B, Aksel G, Kilicli E, Muratoglu M, Kavalci C, Gulalp B, et al. Metoclopramide-induced acute dystonic reaction misinterpreted as conversion disorder and seizure. Eur J Gen Med. 2017;14(4):122-4.

18. Campbell D. The management of acute dystonic reactions. Aust Prescr. 2001;24:19-20

19. van Harten PN, Hoek HW, Kahn RS. Acute dystonia induced by drug treatment. BMJ. 1999;319(7210):623-6.

20. Devaraj NK, Aneesa AR, Abdul Hadi AM, Shaira N. Topical corticosteroids in clinical practice. Med J Malays. 2019;74(2):187-9.

21. Devaraj NK. A recurrent cutaneous eruption. BMJ Case Rep. 2019. https:// doi.org/10.1136/bcr-2018-228355.

\section{Publisher's Note}

Springer Nature remains neutral with regard to jurisdictional claims in published maps and institutional affiliations.
Ready to submit your research? Choose BMC and benefit from:

- fast, convenient online submission

- thorough peer review by experienced researchers in your field

- rapid publication on acceptance

- support for research data, including large and complex data types

- gold Open Access which fosters wider collaboration and increased citations

- maximum visibility for your research: over 100M website views per year

At BMC, research is always in progress.

Learn more biomedcentral.com/submissions 